DOI: $10.17805 / z p u .2021 .4 .16$

\title{
Символика блина как ритуальной пищи в обрядах и обычаях восточных славян
}

\author{
А. В. АЛЕКСАНДРОВА \\ МОСКОВСКИЙ ФИНАНСОВО-ПРОМЫШЛЕННЫЙ УНИВЕРСИТЕТ «СИНЕРГИЯ»
}

Статья посвящена исследованию глубинного смысла общеизвестной ритуальной пищи - блинов. Это традиционное блюдо восточных славян использовалось во многих обрядах, дожило оно и до наших дней. Однако суть самих ритуалов давно утратилась. Возникновение блинов как обрядовой пищи уходит в глубокую древность. Многие исследователи отмечают связь блинов с поминальным обрядом, однако эта обрядовая еда используется и во время свадьбы, и при родинах, и на крестинах, и на день Вознесения Христа, и на Рождество, и на народные праздники, связанные с равноденствием. Как выяснил автор, используя сравнительный метод, сопоставляя различные обряды с применением блинов, все они так или иначе связаны с моментом перехода из одного состояния в другое, а также перехода из этого мира в мир «иной» и обратно. Подобный вывод позволяет утверждать, что обряды с применением блинов возникли на заре нашей цивилизации, в эпоху «мифологического» мировоззрения. Плоские лепешки для поминовения предков упоминаются в древнеиндийских текстах. Исследуя древние корни, связанные с переходом, автор делает предположение, что, возможно, связь их со словом «блин» когда-то была явной, но в настоящее время она утрачена. Автор надеется, что данная статья поможет лучше понять наши культурные традиции.

Ключевые слова: блин; символ; переход; бесконечность; народная культура; календарные праздники; Масленица

\section{ВВЕАЕНИЕ}

B условиях резких общественных и культурных потрясений в России и мире в целом важно не потерять культурные ориентиры, точнее, свою идентичность. Вне культуры бытие человека невозможно. Культура постигается через предметы, окружающие человека, через слово, обряды, обычаи. Национальный культурный менталитет осмысливается при внимательном изучении народных традиций.

Одним из древнейших календарных праздников, дошедших до наших дней из глубокого прошлого, является Масленица. Главный атрибут Масленицы - блины. Общепринятой и растиражированной версией является версия о том, что блин связан с солярной символикой. Создается впечатление, что все просто и ясно. Между тем все, кто изучает фольклор, интересуется этнографией профессионально, не могут не понимать сложности этой проблемы. То, что блин является символом солнца, признается далеко не всеми.

В частности, этой версии (о том, что блин - символ солнца) придерживались представители мифологической школы в XIX в. Но спустя годы мы можем сказать, что истинная заслуга представителей мифологической школы состоит в собирании и систематизации огромного фактического материала, однако многие выводы, сделанные ими, не подтвердились. Приведем цитату из работы А. Н. Афанасьева: «Одновременно с пробуждением природы от зимнего сна (омертвения), пробуждаются к жизни и души усопших, осужденные прибывать в воздушных и заоблачных сферах; поэтому праздник весны был вместе и праздником в честь усопших предков, обычной порой сношений с ними, посещения кладбищ и поминок. Ао сих пор на масленицу бегают по улицам ряженые, что знаменует появление освободившихся из загробного царства стихийных духов-оборотней, и во всех домах приго- 
товляются блины» (Афанасьев, 2002: 660-661). Аалее речь идет о том, что поминают усопших блинами. Афанасьев не говорит прямо, что блины символизируют солнце, но этот вывод напрашивается сам собой, ведь именно солнце пробуждает души предков, а праздник в честь усопших является и праздником весны, когда без солярного символа не обойтись. Академик Б. А. Рыбаков в 80-х гг. XX в. рассматривал изготовление и массовое поедание блинов как «победу дня над ночью, света над тьмой» (Рыбаков, 1987: 668), открыто заявляя, что блины - это символ солнца. Он мотивировал это тем, что «в русских деревнях IX-X вв. известны круглые глиняные сковородки с зубчатыми краями и с прочерченным еще по сырой глине крестом, знаком солнца. Вероятно, они делались для выпечки масленичных блинов» (там же).

Подобные находки не были массовыми. Кроме того, нет никаких данных о том, что в них выпекались блины. Очень возможно, что они использовались для других целей. Однако для советской науки Б. А. Рыбаков был настолько маститой фигурой, что его слова о блинах как о символе солнца для многих стали истиной в последней инстанции.

В художественной литературе можно найти слова А. Н. Куприна, что «блин символ солнца, красных дней, хороших урожаев, ладных браков и здоровых детей» (Куприн, 2015: 228). Такое объяснение очень удобно, оно годится для всех возрастов, даже для самых маленьких.

В 1886 г. А. П. Чехов в своем очерке «Блины» сказал, что «многоговорящие старики-блины, помимо кулинарии и чревоугодия, имеют и другие конечные цели... Кроме тяжелого, трудно переваримого теста, в них скрыто еще что-то более высшее, символическое, быть может, даже пророческое... Но что именно?» (Чехов, 1976: 360).

\section{МАСАЕНИЦА}

Чтобы понять, что же символизирует блин как ритуальная еда, необходимо проследить, где конкретно он употребляется, при каких обстоятельствах. Поскольку широко известно, что блины приурочены к Масленице, то начнем с нее. Итак, что за праздник Масленица? Практически все ученые сходятся на том, что Масленица - сложнейший обрядовый комплекс. Одна часть этого комплекса направлена на встречу весны и проводы зимы, вторая часть связана с поминальными обрядами, а третья часть комплекса относится к семейно-брачной тематике.

Из-за переноса нового года в разные эпохи в разных системах то на одну, то на другую дату смещался весь календарь. Так, в XVII в. гражданский новый год начинался с марта, церковный новый год был с сентября, а народный новый год приурочивался ко дню зимнего солнцеворота (солнцестояния) 21-22 декабря.

Визуально точка, в которой Солнце пребывает в полдень, с каждым днем в течение зимы и весны становится выше над уровнем горизонта. В день летнего солнцестояния светило «останавливается», а после этого точка пребывания солнца в полдень начинает с каждым днем опускаться все ниже. В момент зимнего солнцестояния опять «останавливается» и начинает ежедневно подниматься над горизонтом. Середина этого процесса (между солнцестояниями) называется равноденствием (весеннее и осеннее). С этого момента (равноденствия) начинается период в Северном полушарии, когда день длиннее ночи, и длится он от весеннего до осеннего равноденствия. 
Аревняя Масленица была посвящена весеннему равноденствию (20/21 марта). Однако стоит отметить жесткое давление церкви на языческую культуру, вследствие чего многие народные праздники были смещены и привязаны к церковным. Так, языческая встреча зимы и весны/лета (приходившаяся на равноденствие) оказалась приуроченной к церковному Сретенью (15 февраля). «В Сретение солнце на лето, зима на мороз поворотила», - говорили крестьяне. То есть здесь мы имеем дело с переходом из одного состояния в другое: зима переходит в лето. Этот момент и отмечался ритуальными действиями, которые мы встречаем в Масленичном комплексе. Но смысловая нагрузка перекинулась на Сретение.

Сама же Масленица оказалась привязанной к Великому посту, предшествуя ему. Великий пост, в свою очередь, привязан к христианской Пасхе и начинается за 7 недель до нее. Пасха - праздник с плавающей датой, поэтому и Масленичный комплекс вынужден был все время смещаться, зачастую теряя свои исконные смыслы.

Очень мощным устойчивым компонентом Масленичного комплекса является поминальная обрядовость. Под Масленичным комплексом во временно́м плане подразумевается не только сама Масленичная неделя, но и все предыдущие дни, отмеченные ритуальными действиями. Ао Масленичной недели были еще всеёдная, рябая/пестрая и поминальная (она же дзедава́я и ма́сленьı дедъ́) (Толстая, 2005: $57,74)$. «Перед Ма́сленкой поминальная неделя зовется» - говорили в с. Новая Погощь, Суземского района Брянской области (Пашина, 2006: 213). В народе считалось, что на этой неделе, особенно в пятницу и субботу, души умерших предков появлялись незримо в домах своих потомков. Поэтому на столах для них всегда оставляли угощение. В эти дни поминали родителей блинами и спиртными напитками, если последние были в наличии. Но все это не принимало такого широкого размаха, как на Масленой неделе.

Масленичная неделя делилась на две части: малую и большую или узкую и широкую. Во время малой/узкой Масленицы днем разрешалось работать, а вечера назывались святыми, и работы запрещались. С четверга, когда начиналась большая/широкая Масленица, работы по хозяйству запрещались полностью. Пятницу, субботу и воскресенье Масленичной недели называли прощеныљии, особенно выделяя ритуальными практиками воскресенье.

Поминальные обряды особенно мощно проявляются во время Масленичной недели в приготовлении блинов и манипуляций с ними. О. А. Пашина указывает: «...деление недели на две части сказывалось и в приготовлении блинов. Ср.: "На Ма́сленку у нас так было́: у поняде́льник пякли блины оўся́ныя, с оўся́ной муки. Понядельник, ўторник, сряда. У чатве́рьг - ужа́ пашенишные. У пятницу, у суботу и на за́говины - все это пашенйшные бляны" (А. Заборье, Аемидовского района, Смоленской области)» (там же). Автору данной статьи встречались и другие данные, когда с четверга пекли овсяные блины, а с понедельника - пшеничные. Есть данные и о том, что всю неделю пекли блины из муки одного вида. Эта проблема требует отдельного исследования: в каких местностях используют ту или иную практику, есть ли в этом какая-либо закономерность.

Интересным является процесс приготовления блинов с заговорами на молодой месяц, в отсутствие посторонних, с замешиванием теста на воде, образованной путем таяния снега. О. А. Пашина говорит, что «снег является одной из ипостасей душ умерших» (там же: 225). Это подтверждается обычаем колядовать только по- 
сле того, как выпал снег, что гарантировало налаживание контакта между «тем» и «этим» светом.

Первый испеченный на Масленую неделю блин посвящался покойным родственникам, его клали на слуховое окно или на божницу (Соколова, 1979: 48). Или же его съедала хозяйка, со словами: «Помянем родителей». Зафиксированы случаи, когда первый блин относили на кладбище и клали на могилу близких родственников (Жарникова, 2003a: 35).

\section{ГАДАНИЯ С БАИНАМИ}

Распространенными были гадания при помощи блинов. Незамужние девушки клали блин на голову и шли к соседям под дверь - слушать. Если в разговоре услышат «иди» - значит выйдет замуж, если «сядь, сиди» - не выйдет на этот год. Аругим вариантом гадания был такой: девушки выходили с блином на улицу и у первого встречного, кто соглашался взять блин, спрашивали имя/фамилию. Считалось, что такие имя/фамилия будут у будущего мужа (Народная традиционная культура ..., 2002: 50). Кроме девушек в гаданиях могли принимать участие и дети. Есть сведения о том, что первый испеченный блин отдавали ребенку, он прогрызал в нем дырки - глаза и рот, прикладывал к лицу в виде маски и выходил на улицу или крыльцо слушать. Потом услышанное толковалось как некое предзнаменование (ААФ, Архангельская обл., Каргопольский р-н, с. Тихманьга, 2002. Зап. от А. В. Бахметовой, 1938 г. р.). На Святки бегали с «кокорой» (лепешкой, блином) в зубах по деревне (в чужую деревню) и слушали под окнами. Спрашивали имя первого встречного - так будут звать и жениха (или кто попадется, тот и жених) (Народная традиционная культура ..., 2002: 49). На Святки мы опять имеем дело с переходом Солнца из одного состояния в другое во время зимнего солнцеворота, и опять задействованы блины.

Таким образом, гадающие отождествляли себя с усопшими предками, посредством блина устраивая им переход из «того» света в «этот», одалживая им на время свое тело. Считалось, что предки, находясь в ином мире и в ином состоянии, могли быть ясновидящими, видеть и слышать все, что было, есть и будет в окружающем мире. Гадающий как бы начинал воспринимать мир так, как воспринимали его усопшие. Та же самая ситуация происходит с ряжеными и колядующими. Кстати, колядки пелись и на Масленицу. Соответственно, колядников одаривали блинами. Этнограф, лингвист, фольклорист П. В. Шейн в XIX в. утверждал, что крестьяне считают, «будто надежным способом связи с иным миром является обычай печь блины» (цит. по: Жарникова, 2003а: 36).

В последний день Масленицы, в Прощеное воскресенье, жгли костры, куда кидали блины, приговаривая: «Гори блин, гори Масленица» (Соколова, 1979: 18). Также был распространен обычай вкладывать блин в руки чучелу Масленицы, с которым ее потом и сжигали (Аемченко, 2016: 35). Это не только прощание с Масленицей, но и со своими предками. Есть такой обычай, называемый «греть родителей». Он состоит в том, что в первый день Рождества разжигают большой костер из соломы, ожидая, что умершие предки придут с «того света» погреться. Участники обряда стоят вокруг в торжественном настроении. Но, как вариант, вокруг костра радостно водят хороводы, как на Радунице (Максимов, 1903: 218). Можно сказать, что бросание блинов в костер - завершение акта общения с предками во время масленичных ритуалов. Этнограф, диалектолог, фольклорист А. К. Зеленин указы- 
вает на то, что разжигание костров с целью погреть пришедших с того света предков способствует хорошему урожаю пшеницы (Зеленин, 1909: 256). Аа и любой контакт с предками направлен на улучшении жизни в этом мире. А блины - это средство, с помощью которого эти контакты осуществлялись, вернее осуществлялся переход из этого мира в «иной» и из «иного» в этот, из одного состояния в другое.

\section{СЕМЕЙНО-БРАЧНЫЕ ОБРЯАЫ}

Масленичный комплекс также включает обряды брачно-семейной символики, которые непосредственно связаны с блинами. Существует обычай «посещения молодухами (первый год состоящих в браке) своих родителей, поскольку считалось, что именно на Масленицу заканчивался цикл свадебных обрядов и происходило окончательное отчуждение молодой женщины от своего рода. Угощали молодых обязательно блинами. На Масленицу в Псковской губернии приходился обычай ритуального выкупа молодой жены у ее родной общины (в основном у мужского населения), помимо денег выкупом служили блины, либо их ели после осуществления этого действия» (Борисова, Верняев, Гадло, 1998: 225). Здесь мы опять имеем дело с переходом молодой жены из одного состояния в другое, из одного рода она переходила в другой, менялся ее социальный статус. А. К. Байбурин пишет: «Брачная обрядность оказывается соотнесенной со всеми ритмами, на которые распространяет свое структурирующее воздействие календарь. Следовательно, “социализация" новобрачных приобретает более широкий “космический” смысл» (Байбурин, 1993: 88-89).

Вот еще обычай, связанный с этой темой. На Масленицу молодежь собиралась на возвышенностях, покрытых снегом. «Аевушки клали на свои головы по блину и пели масленичные песни. Парень мог схватить блин у той девушки, которая понравилась ему, и съесть его» (Обрядовая поэзия, 1989: 151). В Масленицу, как и в Святки, обычно выбирали невест. Опять задействован блин как средство для общения с предками. Ведь парень мог ошибиться в своем выборе. Съедая блин, он обращался к предкам за помощью в правильном выборе, а это ни много ни мало продление рода. Аевушка, положив блин на голову, также вручала судьбу своим предкам. Конечно же, все это делалось на бессознательном уровне, поскольку смысл многих обрядов уже был утрачен.

Многие этнографы отмечают обычай на Масленицу зарывать молодоженов в снег. Аибо просто их вываливали в снежном сугробе, либо специально копали яму, сажали туда молодую пару и закидывали полностью снегом, через несколько минут обратно откапывали (Соколова, 1979: 40). Как уже было сказано, снег в народном сознании ассоциировался с душами умерших родственников. Блины, которые ели на Масленицу, замешивались на талой воде. Здесь мы имеем дело с переходом из одного мира в другой, чтобы тот, другой, послал в «этот» мир новые жизни. В народе считается, что ничто не уходит навсегда. Ауши предков вновь могут явиться в этот мир в виде детей. Нужно только показать представителям иного мира, что они здесь желанны, объединиться с тем миром, создать момент перехода.

Блины являются непременным атрибутом свадебного обряда. Об одной стороне их символики уже сказано, но есть еще и другая. Блины во время свадебного/послесвадебного ритуала также могли означать утраченную девственность невесты. «У русских широко распространено угощение молодого на второй день свадьбы, во время которого он с помощью определенных действий с блинами демонстриро- 
вал, сохранила ли невеста девственность до брака. Если девушка оказалась «честной», новобрачный разбивал тарелку из-под блинов, кусал или протыкал ножом блин, откусывал блин с краю, бережно брал, а не комкал блин, дарил матери невесты рубль. Если же невеста утрачивала девственность до свадьбы, то жених откусывал середину блина, клал его на стопку блинов и не ел их, вырезал в блинах клин, давал теще мелочь вместо целого рубля, дарил ей «худой» блин» (Гревцова, 2016: 101-102). Здесь блин выступает в роли символа целостности. Зафиксирован также обычай, когда на следующий день после брачной ночи новоиспеченный муж при праздничной трапезе в кругу родственников проедал в блине дыру, а затем в эту дыру лил вино. Опять-таки мы имеем дело с символическим переходом из одного состояния в другое (из девушки в женщину).

\section{ПРИМЕНЕНИЕ БАИНОВ В АРУГИЕ ПРАЗАНИКИ И ОСОБО ОТМЕЧЕННЫЕ АНИ}

Ритуальные действия с блинами осуществлялись не только на Масленицу. Шейн указывает, что на Вознесение нужно непременно печь блины - «мосьциць Хрысту дорогу на небо» (Шейн, 1902: 18). Здесь тоже налицо символ перехода.

Есть такая закличка весны: «Жаворонки, прилятайте к нам, тут кисели талкуть, тут блины пекуть» (Агапкина, 2000: 40). Блины и кисель - традиционная еда, связанная с поминальным обрядом. Но в данном случае лучше сказать - связанная с переходом из зимы в весну. Певчие птицы всегда считались атрибутом рая. О теплых краях в деревнях того времени ничего не знали, а о том, что в раю цветут цветы и туда улетают на зиму птицы, знали все верующие. Вот их и привлекали из рая назад, в наш мир, чтобы наступила настоящая весна.

В течение всех трех дней Троицы, как и на Масленицу, ели блины, только поедали их, расположившись на ржаном поле (чтобы рожь уродилась). По южнорусским обычаям блины подают колядующим (кроме них могут раздавать странникам, нищим), и блины же ставят в хлев для домовых на Крещение (Жарникова, 2003a: 84).

Блины выпекались и на Рождество Христово. Пропп утверждал, что в русском народе был распространен обычай в рождественскую ночь поминать не просто покойников как таковых, а именно предков своей семьи (Пропп, 2006: 20-21).

Обряды родин и крестин тоже сопровождались блинами. «Родственники приходят навещать новорожденного, беря с собой по традиции пироги, блины и другие кушанья (Родины, дети, повитухи ..., 2001: 90). Обязательным блюдом на званом обеде после крестин были шаньги (блины с толокном) и клюквенный кисель (Чухина, 2004: 51). Еще интересное поверье, связанное с блинами: если перенашиваешь беременность, то для скорейших родов нужно поесть блинов (Родины, дети, повитухи ... , 2001: 232). И понятно, почему: нужно осуществить связь с предками, и они помогут, сделают так, чтобы ребенок обязательно пришел в этот мир, не дадут пресечься роду. Или такая интерпретация: переход младенца из утробы матери в этот мир.

\section{ЗАКАЮЧЕНИЕ}

Итак, манипуляции, которые проводили с блином, следующие: его можно съесть, положить возле чтимого места (божница, могила предков, высокое место в доме (слуховое окно), использовать в виде маски, применить в качестве атрибута 
гадания (держание в руках, в зубах, на голове, за пазухой), подать людям, совершающим обрядовые действия (колядующим), или людям, которые представляют собой посланцев с того света (ряженые, странники, нищие), угостить им потусторонних существ (умерших предков, домовых), сжечь в костре. То есть это не просто еда, пусть и ритуальная, - это гораздо больше.

Если кутья (еще одно ритуальное блюдо), как каша из цельных зерен и семян, представляла собой переход из семени в растение и опять в семя, т. е. вечный круговорот жизни, то блин мог символизировать такой оборот. Тогда понятно, почему эти блюда (кутья и блины) использовались в обрядах свадьбы и похорон/поминок. Ведь жених и невеста «умирали» в качестве таковых и «рождались» вновь в качестве мужа и жены. Мало того, невеста «умирала» для своего рода и «возрождалась» в роде мужа. Кстати, через год после свадьбы этот процесс отчуждения жены от прежнего рода завершался. Отсюда масленичные семейные обряды, связанные с блинами.

В природе процесс смены жизни и смерти зациклен. Поэтому смерть не является конечной точкой. Аревние славяне верили в бесконечность жизни, целостность природных процессов. Символом бесконечности всегда был круг, что и прослеживается в ритуальной пище - блинах, которые специально применяются в родинах, на свадьбе и в похоронном обряде. Будучи круглыми и незаменимыми во всех семейных обрядах, блины были олицетворением бесконечности бытия и свидетельствовали о цикличности жизни. «Такой взгляд на происходящие изменения в семейной жизни человека позволяет русским старожилам стоически переносить безвременную смерть близких людей, высокую смертность детей в младенчестве» (Андриевич, 2012: 224).

Один из текстов Махабхараты (Махабхарата, 1984: 80-81) рассказывает о том, что «первые предки возникли из трех комов земли, превращенных Творцом в лепешки» (Жарникова, 2003b: 111).

Именно плоскими лепешками (блинами) велел Бог-Творец поминать и почитать ушедших предков, наделив их вечным существованием в мире ином.

Почему же столь древние обрядовые формы и представления дошли до наших дней? Аело в том, что принятое христианство и старые языческие обычаи сильно разнились в своей основе, и народ сохранил то, что ему было ближе. Интересно об этом рассуждает Ю. М. Аотман в статье «“Аоговор” и “вручение себя” как архетипические модели культуры» (Иотман, 1993: 346). Святой Августин (Блаженный) считал, что конечное спасение или проклятие человека не зависит от его добродетели, а целиком определяется произволом Бога. По большому счету суть христианской религии для обывателя - это постоянное вымаливание и выпрашивание милостей от Бога. Что же касается сути языческого комплекса верований, которого придерживались восточные славяне, то «попрошайничество» здесь отсутствует.

Потому-то и дожили древние языческие обычаи до начала ХХ в., что христианский подход не давал никаких гарантий, так необходимых земледельцу, гарантий хорошего урожая (будешь ли замечен Богом, нет ли), а значит, достатка в питании, достатка в жизни, как следствие, продления рода. Напротив, в языческой среде предков, играющих роль хтонических богов, во время определенных дней поддерживают пищей, приглашают за свой семейный праздничный стол, приносят им пищу на могилы, приглашают обогреться у костра, выражают им свою любовь и почтение. Это с одной стороны, а с другой - нужно было показать и себя, доказать, 
что именно ты достойный член рода, чтобы именно тебе, ловкому и сильному, был дарован богатый урожай, чтобы можно было продлевать свой род и дальше. Именно поэтому считалось, что лен вырастет у того выше, кто ловчее и дальше съедет с ледяной горы на Масленицу, что рожь уродится лучше у того, кто выше прыгнет, именно поэтому плясали до упаду на могилах во время Радуницы, рады были с лучших сторон показать себя своим предкам, обратить на себя их внимание, а соответственно, и получить хороший урожай. Но для того чтобы было кого уверять в своей удали, чтобы было кого уверять в своем уважительном отношении, нужно было обеспечить предкам бессмертие. Как природа участвует в круговороте жизнь смерть - жизнь, так и ушедшие предки должны были участвовать в этом вращении, в этом переходе. Вот здесь-то и приходила на помощь ритуальная еда: кутья, как символ жизни, невзирающей на смерть; яйца, как символ воскресения; блинь, как символ перехода и бесконечности этого прочесса.

Этимология слова «блин» в словаре П. Я. Черных (Черных, 2001: 94) возводится к слову млинь (XIV в.), встречающемуся в украинском, болгарском, словенском, чешском, польском, нижнелужицком языках. Причем слово это в разных языках имеет разное значение, не везде оно подразумевает то, что мы понимаем под словом «блин». Само же слово «млинъ» выводится от тьlinъ - «мельница» (жернов, нечто круглое). Форма слова «блин» (XV в.) встречается кроме русского еще и в белорусском, болгарском, чешском и польском. Словарь указывает на то, что общеславянское слово восходит (предположительно!) к позднелатинскому molinum «мельница». П. Я. Черных, как видим, очень осторожно подходит к происхождению слова «блин». Есть ученые, которые не согласны с таким происхождением (Г. А. Ильинский, Х. Шёльд), но каких-то своих убедительных версий не выдвигают. Надо полагать, что окончательной точки в происхождении слова «блин» пока не поставлено.

Интересное наблюдение: в санскритско-русском словаре (Санскритско-русский ..., 2020: 129) есть понятие, сравнимое с функцией блина.

बलि bali $m$ подаяние; жертвенная пища, приносимая сверхъествественным существам;

nom. pr. Бали, демон, царь дайтьев

बल्डिन् balin сильный; мужественный, могучий; $m$ воин

Как блин является жертвенной пищей, приносимой сверхъестественным (потусторонним) существам, так и bali. Только у восточных славян под этими потусторонними подразумеваются умершие предки, играющие роль хтонических богов, а у племен, пользующихся санскритом, под сверхъестественными подразумеваются дайтьи, демоны. В любом случае, обращение к этим существам, подношение им ритуальной еды осуществляется с целью улучшения жизни в этом мире (хороший урожай, здоровье, сила, продление рода и т. А.). И, как видим, такие контакты посредством bali осуществлялись и давали положительные результаты - в санскрите есть однокоренное слово balin - сильный, мужественный, могучий, в том числе воин (защитник).

Русский язык вполне сравним с санскритом. Крупнейший в России специалист по ведийской культуре, российский лингвист и профессиональный переводчик «Ригведы» Т. Я. Елизаренкова, сравнивая санскрит и русский язык, пишет: «...при переводе с ведийского на другие языки русский язык обладает рядом несомненных 
преимуществ перед западноевропейскими языками. Эти преимущества определяются как большей степенью соответствия между ведийским и русским в силу лучшей сохранности в нем архаизмов, чем в западных языках, так и большей близостью русской (славянской) мифопоэтической традиции к индоиранской» (Елизаренкова, 1989: 53).

Кстати, тонкие лепешки для поминания предков, сравнимые по качеству и функции с нашими блинами, упоминаются в «Махабхарате», написанной на санскрите. В одном из мифов говориться, что Бали был владыкой подземного мира (Мифы народов мира, 2008: 125).

Интересно, что демон Бали также в некоторых древних текстах называется Вала. Аревние корни *wal- и *bal- идентичны. К этому ряду принадлежат и корни *wel-, *fil-. Весь этот ряд корней семантически связан с переходом, в том числе из этого мира в «иной» и назад. Можно сравнить: балт. welli - «день мертвых» (день, когда молились Велесу (владыка загробного царства и бог знаний) о душах умерших, чтобы он проводил их в Правь); литов. veles - «тени усопших», vele - «душа»; сканд. valkyrja - «валькирия» (букв. «выбирающая мертвых, убитых») и т. А. (Ишутин, 2004: 32).

Подведем итоги. Блины - одно из древнейших блюд. Из глубины веков до нас дошли отголоски магических представлений и действий, связанных с этой обрядовой пищей. Применение блинов в обрядах не исчерпывается их похоронно-поминальной тематикой. Если в свадебном обряде мы можем проследить эту закономерность ( «умирание» невесты для своего рода и «возрождение» ее же для рода мужа, «умирание» жениха и невесты и «возрождение» мужа и жены), то в обрядах рождения и крещения младенца такой связи нет. Нет такой связи и в обрядах, посвященных солнцестоянию (равноденствию). Но во всех без исключения этих обрядах и ритуалах мы наблюдаем переход из одного качества или состояния в другое. Именно момент перехода, его возможность, бесконечность этой возможности и символизирует блин как ритуальная еда. Конечно же, здесь имеет значение символика круга, как зацикливание, бесконечность процесса. Но при этом нужно обязательно помнить про сам процесс, так как его наличие первично - процесс перехода. Семантически слово «блин» вполне может принадлежать к ряду древних корней, обозначающих переход. Однако в силу развития общества первоначальный смысл был утрачен. Остались только некоторые ритуалы и манипуляции, которые современные люди, проделывающие их, уже не могут объяснить. Но для понимания того, что было утрачено, как меняются со временем обычаи и народное сознание, куда движется наше общество в культурном плане, необходимо извлекать утраченные смыслы.

\section{СПИСОК АИТЕРАТУРЫ}

Агапкина, Т. А. (2000) Этнографические связи календарных песен. Встреча весны в обрядах и фольклоре восточных славян. М. : Индрик. 336 с.

Андриевич, И. А. (2012) Аексика семейных обрядов как способ представления культуры в рамках сценария // Вестник ИрГТУ. № 7 (66). С. 223-227.

Афанасьев, А. Н. (2002) Мифы, поверья и суеверия славян. Поэтические воззрения славян на природу : в 3 т. Т. 3. М. : Эксмо ; СПб. : Terra Fantastica. 768 с.

Байбурин, А. К. (1993) Ритуал в традиционной культуре: структурно-семантический анализ восточнославянских обрядов. СПб. : Наука. 240 с. 
Борисова, В. И., Верняев, И. И., Гадло, А. В. (1998) Историко-этнографические очерки Псковского края. Псков : Псковский областной институт повышения квалификации работников образования. 315 с.

Гревцова, Т. Е. (2016) Блины в свадебном ритуале: культурная терминология и обрядовая семантика // Аингвокультурология. № 10. С. 98-109.

Аемченко, П. Н. (2016) Поминовение усопших, ряжение и обильная еда как акциональные блоки в масленице // Манускипт. № 7 (69) : в 2 ч. Ч. 1. С. 34-36.

Елизаренкова, Т. Я. (1989) «Ригведа»- великое начало индийской литературы и культуры. Мандалы I-IV. М. : Наука. 768 с.

Жарникова, С. В. (2003а) Исторические корни календарных обрядов. Вологда : Областной научно-методический центр культуры и повышения квалификации. 84 с.

Жарникова, С. В. (2003b) Золотая нить. Вологда : Областной научно-методический центр культуры и повышения квалификации. 221 с. : ил.

Зеленин, А. К. (1909) Народный обычай греть покойников // Сборник Харьковского историко-филологического общества : в 21 т. Т. 18. С. 256-271.

Ишутин, А. А. (2004) Восточнославянская теонимия. Воронеж : Воронежский госпедуниверситет. 112 с.

Куприн, А. И. (2015) Юнкера. М. : Азбука. 320 с.

Иотман, Ю. М. (1993) «Аоговор» и «вручение себя» как архетипические модели культуры // Избр. ст. : в 3 т. Т. 3. Таллин. 480 с. С. 345-355.

Максимов, С. В. (1903) Нечистая, неведомая и крестная сила. Санкт-Петербург : Т-во Р. Голике и А. Вильборг. [2], IV, 526, III с.; 22 см. (Этнографическое бюро князя В. Н. Тенишева). 529 с.

Махабхарата (1984) Вып. V. Кн. 2. Нараяния / пер., прим. и толковый словарь Б. А. Смирнова. Ашхабад : Ылым. 328 с.

Мифы народов мира (2008). Энциклопедия / под ред. С. А. Токарева. М. : Советская энциклопедия. Электронное издание. 1147 с.

Народная традиционная культура Псковской области: Обзор экспедиционных материалов из научных фондов Фольклорно-этнографического центра (2002) : в 2 т. Псков : Издательство Областного центра народного творчества. Т. 1. 688 с. : ил., нот.

Обрядовая поэзия (1989) / сост., предисл., примеч., подгот. текстов В. И. Жекулиной, А. Н. Розова. М. : Современник. 735 с. : ил.

Пашина, О. А. (2006) Календарно-песенный цикл у восточных славян. СПб. : Композитор. Санкт-Петербург. 280 с.

Пропп, В. Я. (2006) Русские аграрные праздники. Опыт историко-этнографического исследования. М. : Аабиринт. 176 с.

Родины, дети, повитухи в традициях народной культуры (2001) / сост. Е. А. Белоусова ; отв. ред. С. Ю. Неклюдов. М. : Российск. гос. гуманит. ун-т. 319 с.

Рыбаков, Б. А. (1987) Язычество Аревней Руси. М. : Наука. 784 с.

Санскритско-русский учебный словарь (2020). Около 6000 слов / сост. Н. П. Аихушина. Версия 10.1 от 30.01.2020. 217 с. Электронное издание.

Соколова, В. К. (1979) Весенне-летние календарные обряды русских, украинцев и белорусов, XIX - начало XX в. М. : Наука. 288 с.

Толстая, С. М. (2005) Полесский народный календарь. М. : Индрик. 600 с.

Черных, П. Я. (2001) Историко-этимологический словарь современного русского языка : в 2 т. 4-е изА., стереотип. М. : Рус. яз. Т. 1.624 с.

Чехов, А. П. (1976) Блины // Полн. собр. соч. и писем : в 30 т. ; Соч. : в 18 т. / АН СССР. Ин-т мировой лит. им. А. М. Горького. Т. 4. [Рассказы, юморески], 1885-1886. М. : Наука. C. $360-363$.

Чухина, А. А. (2004) Свадьба, родины и похороны в Каргополье // Живая старина. № 2. C. 49-51. 
Шейн, П. В. (1902) Материалы для изучения быта и языка русского населения СевероЗападного края : в 3 т. Т. 3. СПб. : Типография Императорской академии наук. 536 с.

Аата поступления: 15.07.2021 2.

\section{THE SYMBOLISM OF THE PANCAKE AS A RITUAL FOOD IN THE CEREMONIES AND CUSTOMS OF THE EASTERN SLAVS}

\section{A. V. ALEKSANDROVA}

MOSCOW UNIVERSITY FOR INDUSTRY AND FINANCE "SYNERGY"

The article is devoted to the study of the deep meaning of the well-known ritual food - pancakes. This traditional dish of the Eastern Slavs was used in many rituals, and it still exists today. However, the essence of the rituals themselves has long been lost. The origin of pancakes as a ritual food goes back to ancient times. Many researchers note the connection of pancakes with the funeral rite, but this ritual food is also used during weddings, at childbirth celebrations, at christenings, on the day of the Ascension of Christ, at Christmas, and on national holidays associated with the equinox. With the help of the comparative method, and contrasting various rituals with the use of pancakes, the author has discovered that they are all somehow connected with the moment of transition from one state to another, as well as the transition from this world to the "other" world and back. Such a conclusion suggests that the rituals with the use of pancakes originated at the dawn of our civilization, in the era of the "mythological" worldview. Flat cakes for commemorating ancestors are mentioned in ancient Indian texts. The author examines the ancient roots associated with the transition and makes an assumption that, perhaps, their connection with the Russian word "blin" was once obvious, but now it is lost. The author hopes that this article will be useful for a deeper insight into our cultural traditions.

Keywords: pancake; symbol; transition; infinity; folk culture; calendar holidays; Maslenitsa

\section{REFERENCES}

Agapkina, T. A. (2000) Jetnograficheskie svjazi kalendarnyb pesen. Vstrecha vesny $v$ obrjadab $i$ fol'klore vostochnyb slavjan. Moscow, Indrik. 336 p. (In Russ.).

Andrievich, I. L. (2012) Leksika semejnyh obrjadov kak sposob predstavlenija Kul'tury v ramkah scenarija. Vestnik Irkutskogo gosudarstvennogo tekbnicheskogo universiteta, no. 7 (66), pp. 223-227. (In Russ.).

Afanas'ev, A. N. (2002) Mify, pover' ja i sueverija slavjan. Pojeticheskie vozzrenija slavjan na prirodu. In 3 vols. Moscow, Jeksmo; St. Petersburg, Terra Fantastica. Vol. 3.768 p. (In Russ.).

Bajburin, A. K. (1993) Ritual v tradicionnoj kul'ture: strukturno-semanticheskij analiz vostocbnoslavjanskib obrjadov. St. Petersburg, Nauka. 240 p. (In Russ.).

Borisova, V. I., Vernjaev, I. I. and Gadlo, A. V. (1998) Istoriko-jetnograficheskie ocherki Pskovskogo kraja. Pskov, Pskov Regional Institute of Advanced Training of Educational Workers. 315 p. (In Russ.).

Grevcova, T. E. (2016) Bliny v svadebnom rituale: kul'turnaja terminologija i obrjadovaja semantika. Lingvokul'turologija, no. 10, pp. 98-109. (In Russ.).

Demchenko, P. N. (2016) Pominovenie usopshih, rjazhenie i obil'naja eda kak akcional'nye bloki v maslenice. Manuskipt, no 7(69) : in 2 parts. Part 1. Pp. 34-36. (In Russ.).

Elizarenkova, T. Ja. (1989) «Rigveda»-velikoe nachalo indijskoj literatury $i$ kul'tury. Mandaly I-IV. Moscow, Nauka. 768 p. (In Russ.).

Zharnikova, S. V. (2003a) Istoricheskie korni kalendarnyb obrjadov. Vologda, Regional Scientific and Methodological Center of Culture and Professional Development. 84 p. (In Russ.).

Zharnikova, S. V. (2003b) Zolotaja nit'. Vologda, Regional Scientific and Methodological Center of Culture and Professional Development. 221 p. (In Russ.).

Zelenin, D. K. (1909) Narodnyj obychaj gret' pokojnikov. Sbornik Har' kovskogo istoriko-filologicheskogo obshbestva, vol. XVIII, pp. 256. (In Russ.). 
Ishutin, A. A. (2004) Vostochnoslavjanskaja teonimija. Voronezh, Voronezh State Pedagogical Univ. 112 p. (In Russ.).

Kuprin, A. I. (2015) Junkera. Moscow, Azbuka. 320 p. (In Russ.).

Lotman, Ju. M. (1993) «Dogovor» i «vruchenie sebja» kak arhetipicheskie modeli kul'tury. In: Lotman Ju. M. Izbrannye stat' $i$ : in 3 vols. Tallinn, Aleksandra. Vol. 3. 480 p. Pp. 345-355 (In Russ.).

Maksimov, S. V. (1903) Nechistaja, nevedomaja i krestnaja sila. St.-Petersburg, partnership of R. Golike and A. Vilborg. 529 p. (In Russ.).

Mababbarata (1984) Iss. V. Book 2. Narajanija. Ashhabad, Ylym. 328 p. (In Russ.).

Mify narodov mira. Jenciklopedija (2008) / ed. by S. A. Tokarev. Moscow, Sovetskaja jenciklopedija [online] Available at: https://www.indostan.ru/biblioteka/knigi/2730/3412_1_o.pdf (accessed: 15.07.2021).

Narodnaja tradicionnaja kul'tura Pskovskoj oblasti: Obzor jekspedicionnyb materialov iz nauchnyb fondov Fol' klorno-jetnograficheskogo centra (2002). In 2 vols. Pskov, Regional Center of Folk Art. Vol. 1.688 p. (In Russ.).

Obrjadovaja pojezija (1989) Moscow, Sovremennik. 735 p. (In Russ.).

Pashina, O. A. (2006) Kalendarno-pesennyj cikl u vostocbnyb slavjan. St. Petersburg, Kompozitor. 280 p. (In Russ.).

Propp, V.Ja. (2006) Russkie agrarnye prazdniki. Opyt istoriko-jetnograficbeskogo issledovanija. Moscow, Labirint. 176 p. (In Russ.).

Rodiny, deti, povitubi v tradicijab narodnojkul'tury (2001)/ comp. by E.A. Belousova; ed. by S. Ju. Nekljudov. Moscow, Russian State University for the Humanities. 319 p. (In Russ.).

Rybakov, B. A. (1987) Jazychestvo drevnej Rusi. Moscow, Nauka. 784 p. (In Russ.).

Sanskritsko-russkij uchebnyj slovar'. Okolo 6000 slov (2020) / comp. by N. P. Lihushina. Version 10.1 from 30.01.2020 [online] Available at: https://www.galenel.info/ [online] Available at: https://www.galenel.info/sanskrit/Three-manual-vocabulary.pdf (accessed: 15.07.2021).

Sokolova, V. K. (1979) Vesenne-letnie kalendarnye obrjady russkih, ukraincev $i$ belorusov, $X I X$ - nacbalo $X X v$. Moscow, Nauka. 288 p. (In Russ.).

Tolstaja, S. M. (2005) Polesskij narodnyj kalendar'. Moscow, Indrik. 600 p. (In Russ.).

Chernyh, P. Ja. (2001) Istoriko-jetimologicheskij slovar' sovremennogo russkogo jazyka: in 2 vols. 4th ed., stereotyp. Moscow, Russkiy jazyk. Vol. 1. 624 p. (In Russ.).

Chehov, A. P. (1976) Bliny. In: Chehov A. P. Polnoe sobranie sochinenij i pisem: in 30 vols. Sochinenija: in 18 vols. Vol. 4. Rasskazy, jumoreski, 1885-1886. Moscow, Nauka. Pp. 360-363. (In Russ.).

Chuhina, A. A. (2004) Svad'ba, rodiny i pohorony v Kargopol'e. Zhivaja starina, no. 2, pp. 49-51. (In Russ.).

Shejn, P.V. (1902) Materialy dlja izuchenija byta $i$ jazyka russkogo naselenija SeveroZapadnogo kraja. In 3 vols. St. Petersburg, Imperial Academy of Sciences. Vol. 3.536 p. (In Russ.).

Submission date: 15.07.2021.

Александрова Ариадна Викторовна - преподаватель кафедры русского языка и литературы Московского финансово-промышленного университета «Синергия». Адрес: 105318, Россия, г. Москва, ул. Измайловский вал, д. 2. Тел.: 8 (495) 800-10-01. Эл. адрес: qwiny@ mail.ru

Aleksandrova Ariadna Viktorovna, Lecturer, Department of Russian Language and Literature, Moscow University for Industry and Finance "Synergy". Postal address: 2, Izmaylovsky Val St., Moscow, Russian Federation, 105318. Tel: 8 (495) 800-10-01. E-mail: qwiny@mail.ru 